\title{
The Promise and Perils of Aid: The Role of the Nepal Peace Trust Fund (NPTF) Framework in Facilitating Post-Conflict Development in Nepal
}

\author{
Rajib Timalsina
}

\begin{abstract}
Nepal adopted a unique post-conflict development framework for mobilizing international support and government resources to facilitate its peace process. The main focus of this paper is the role played by the Nepal Peace Trust Fund (NPTF) in Nepal's transition. The paper concludes that the main strengths of this model were its success in keeping ex-combatants in cantonments by creating a conducive environment, its harmonization of funds from donors and the government, and its contribution to national elections. However, the NPTF's defects were many, including weak monitoring mechanisms, an inability to prepare for successful rehabilitation and to initiate projects to support transitional justice, and failure to stop the misuse of funds and corruption. Having taken stock of these failures, the paper explores a core reason for them: the NPTF's isolation from the political process.
\end{abstract}

Keywords post-conflict development, government-donor joint initiative, facilitating peace process, Nepal Peace Trust Fund

\section{Introduction}

The decade-long armed conflict between Maoist rebels and the Nepalese state ended in 2006. After three rounds of unsuccessful negotiations, the democratic and rebel forces had come together following a coup led by King Gyanendra in 2004. This led to a popular movement in April 2006 that ended a conflict that had claimed thirteen thousand lives. Subsequently, the seven major political

(C) 2016 The Institute for Peace and Unification Studies, Seoul National University ISSN 2288-2693 Print, ISSN 2288-2707 Online 
parties formed an interim government which was supported by the then rebels. The armed conflict formally ended with the signing of the Comprehensive Peace Accord (CPA) in November 2006 between the rebel forces and the government of Nepal formed by the seven political parties. Following the ceasefire agreements between the government and rebels, both sides agreed to end hostilities and initiate social, political, and economic transformation within the country. Once the CPA was signed, the former rebels came into mainstream politics, joining the interim parliament on the basis of special provisions introduced into the constitution. Since then, the peace process has rested on four main pillars: (1) the rehabilitation and reintegration of ex-combatants, (2) a new constitution and restructuring of the state, (3) reconstruction and post-conflict development, and (4) national and local reconciliation.

Believing that the regular development process was inadequate for addressing the specific post-conflict issues, the government set up the Ministry of Peace and Reconstruction (MoPR) and the Nepal Peace Trust Fund (NPTF) in January 2007. This was considered a significant milestone in the process of transition that would facilitate a return to the normal course of development as quickly as possible. Since then, the NPTF has become the principal body linking the government of Nepal and donor agencies (interviews with NPTF technical adviser, June 26, 2013, and NPTF director, August 11, 2014). Since the NPTF was formed to coordinate the administration of funding from donors and the government, its leadership is made up of political players from Nepal, representatives of the political bureaucracy of the donors, and its own bureaucrats. Despite corruption and accountability issues, as well as the political isolation of the NPTF framework, a significant proportion of NPTF resources has been allocated to the four pillars of the peace process noted above. When I speak of the NPTF's "political isolation," I do not mean that there has been no political involvement in the framework. Indeed, the NPTF board was composed of political leaders, but they have, most of the time, expressed their dissatisfaction with their exclusion from the actual decision-making process. The politicians claim that most of the key decision-making positions are occupied by technocrats and bureaucrats, and the political leaders are only brought in to rubber-stamp these decisions (interview with former NPTF board member from Nepali Congress Party, August 17, 2013). Thus, the dynamics between the different players and the context should be taken into consideration when examining how the NPTF framework operates and its contribution to the main pillars of the peace process.

The NPTF has sought to facilitate Nepal's transition to peace by undertaking a variety of projects. Several of its initiatives designed to support the first three pillars have been successful, though seldom within the intended timeframe. The management of the ex-combatants is thought to have been relatively successful, but its completion missed multiple deadlines. However, the reconstruction of 
infrastructure destroyed in the conflict has been less successful than the other key pillars. In many cases, reconstruction has deteriorated into a matter of kam chalau (make do with what you have) rather than being a planned process. The promulgation of a new constitution, a significant milestone in the peace process, was only recently achieved, and it is still disputed. The national and local reconciliation process has lagged behind the other three pillars. Eight years after the peace accord, the government was finally able to set up a Truth and Reconciliation Commission (TRC). Two years later, the TRC has just set up its national headquarters, started to receive complaints, and is preparing to start its work, while its operational guidelines have yet to be formalized.

This paper focuses on analyzing the role of the NPTF as a special case of the facilitation of post-conflict development policies and practices adopted in Nepal in 2007. The paper is based on a review of the available literature and primary data acquired through semi-structured interviews. The author was given an opportunity to conduct more than 143 semi-structured interviews from July 2013 to October 2015 with key informants and project beneficiaries associated with Nepal's peace process. The interviewees ranged from top political leaders and officials involved in implementing various projects related to the peace process, to local political leaders, social workers, former combatants, project beneficiaries, and Nepalis who took no part in the conflict but were deeply affected by it.

The next section of this paper provides an overview of the context in which the NPTF framework was set up, as well as an outline of the institutional arrangements made for the implementation of joint government-donor efforts. The following section focuses on the achievements of the NPTF framework and the challenges associated with it, including in such areas as the management of ex-combatants and cantonments, assistance for victims of the conflict, transitional justice, the process of drafting the constitution, and the governance system of the NPTF. Finally, the paper concludes that the work of the NPTF framework in bringing together the national government and international donors in resource mobilization had mixed results.

\section{Establishment of the NPTF Framework in Context}

Developing countries such as Nepal receive foreign aid for many development projects every year. To properly manage and coordinate such aid, the government of Nepal established the International Economic Cooperation Coordination Division (IECCD) within the Ministry of Finance (Ministry of Finance 2014). However, it is well documented that donors also invest directly in development projects, often without even coordinating their efforts with the IECCD (Nepal Dispatch 2013). Indeed, policy briefs regularly call for a one-window system for 
channeling foreign aid (Spotlight 2012). The establishment of the NPTF must be understood in this context.

The Peace Secretariat, which was set up to deal with specific issues of postconflict transition, frequently raised the issue of weak coordination among government agencies themselves in setting priorities and managing resources (Peace Secretariat, Government of Nepal 2007; Crisis Group 2006; OECD Joint Evaluation Team 2013; United Nations Nepal Information Platform 2006). In addition, the issue of donor harmonization to avoid overlap in projects and financial assistance was always a major topic of discussion in joint meetings of donors and the government (NPTF 2010b; Peace Secretariat, Government of Nepal 2007). Most stakeholders realized that the regular coordination mechanism set up by the Ministry of Finance was not able to manage the massive influx of aid for the peace process.

The general understanding as reflected in the national press at that time was that regular development practices could not ensure the peace dividend (Spotlight 2012; Nepal Dispatch 2013; NPTF 2008). Two major risks were identified by the Ministry of Finance itself. First, it was feared that the donor community might not fully support regular endeavors. Second, there was concern that the existing line ministries might not take the management of international support for the peace process as seriously as was necessary (Ministry of Finance 2014). Therefore, it was in the interests of both the donors and the government to establish a separate mechanism with a joint basket fund. That was the context in which the Nepal Peace Trust Fund (NPTF), housed within the MoPR, came into being in February 2007. The NPTF had a mandate to implement the CPA and subsequent agreements working under the MoPR.

The NPTF describes itself as a unique and pioneering funding mechanism in the arena of peacebuilding managed by the government and supported by donors (NPTF 2010a; 2010b). Looking at peace funds globally, the United Nations has set up sixty-six multi-partner trust funds to support transition, development, and peace (UN Multi-partner Trust Fund Office 2015). Civil society groups have managed funds for peace through partnerships with multiple donors in Sri Lanka (Orjuela 2005), and the European Union is planning to set up a post-conflict peace fund as part of the Colombian peace process (European Parliament 2016). The NPTF is to date, therefore, the only multi-partner peace trust fund managed by a national government.

Due to the protracted nature of the transition period in Nepal, the mandate of the NPTF was extended three times, in 2009, 2011, and 2014. As per the terms set out in the CPA, the NPTF is mandated to act as a coordinating body for peace-related initiatives, as a funding mechanism for government-donor resources, and to monitor and facilitate the peace process. In this regard, the core mandate of the NPTF is to implement the provisions of the historic CPA and subsequent agreements, thus establishing lasting peace in Nepal (NPTF 2014). 
Regarding the NPTF's institutional arrangements, the government is one of the main funding partners, as well as being the manager and implementer of the post-conflict development projects. The Joint Financial Arrangement (NPTF 2010a) Agreement recognizes the role of donors in supporting the fund in such a way that it can be effective and accountable. The agreement states that donors have promised to assign a chair from their side and to provide technical and financial support. Similarly, political parties and civil society organizations are represented on the NPTF board, the institution's highest decision-making and project-approving body. A technical committee, led by the secretary of the MoPR and composed of other bureaucrats, was set up to assist the board and approve concept notes. At the same time, the framework has identified victims of the conflict, the security sector, and peacebuilding mechanisms at national and local levels as beneficiaries. Until 2014, the NPTF was a platform for harnessing government funds supplemented by contributions from eight other partners, namely, Denmark, the European Union, Finland, Germany, Norway, Switzerland, the United Kingdom, and the United States. Today, only four international donors remain. The NPTF Secretariat was established for the day-to-day management of projects. For the organization of the NPTF, see Figure 1.

Figure 1. Organization of the NPTF

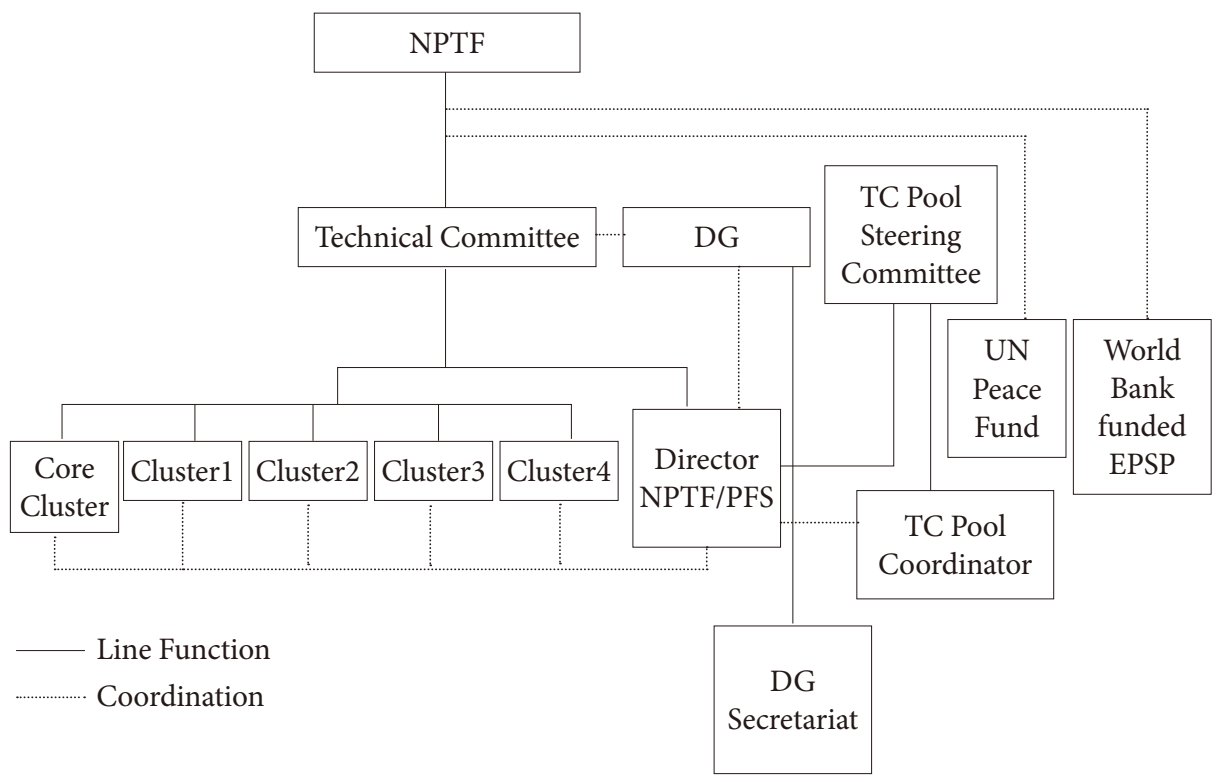

Source: Nepal Peace Trust Fund 2010b.

Notes: DG: Donors Group; EPSP: Emergency Peace Support Project of the World Bank; TC: Technical Committee; PFS: Peace Fund Secretariat. 
Donors, peace scholars, international experts, consultants, government officials, and civil society representatives have their own distinct priorities concerning the peace process in Nepal. Despite the fact that numerous consultations were required before an agreement could be reached, five key areas of peacebuilding which require special attention were identified as the targets of the NPTF's work (NPTF 2008; NPTF 2010b). Those areas are: Maoist combatants in the cantonments; persons and communities affected by the conflict; the reconstruction of public infrastructure damaged during the conflict; the strengthening of law and order, including mechanisms for transitional justice; and the development of the new constitution. Based on those five thematic areas, four "clusters" were set up to carry out the day-to-day functions of the NPTF, focusing on the following areas: cantonment management and integration of combatants, conflict affected people and communities, security and transitional justice, and constituent assembly and peacebuilding initiatives.

\section{NPTF Framework: Achievements and Challenges}

When the peace process started in Nepal, the NPTF framework was mandated to implement the Comprehensive Peace Accord (CPA) and all other subsequent agreements. It was envisaged that the NPTF would facilitate the whole peace process, creating a conducive environment for peace, executing peace-related projects, and monitoring those projects and the entire ongoing peace process in the country. The main task was the CPA, but after that was signed, the government started to conclude numerous, often contradictory, agreements with various armed groups, and that hampered the work of the NPTF by making it more complex. Indeed, between 2006 and the end of 2008, the number of small dissident groups in Nepal had reached 147. The restoration of democracy and the change of regime in the country caused chaos, and social movements raised various issues. For example, there are many ethnic and minority groups in Nepal who had long felt marginalized. They began organizing themselves into identitybased groups and calling for inclusion in mainstream politics. Actually, most of the issues raised were directly or indirectly linked to provisions of the peace agreements. It is obvious that this was a very confusing time for the government and social bodies, and it was difficult for them to decide how they should act. At the same time, the government's efforts to manage diverse dissident groups by means of dialogue and agreements led to the production of multiple contested, dichotomous, and complex documents. It would have been a very complex task to act on all of the clauses in those documents at once. Efforts to meet the demands of dissatisfied groups led to a situation where if some provisions of an agreement with one group were implemented, some clauses in agreements with other groups would be violated. This scenario created unprecedented difficulties for the NPTF. 
It is in this context that I will examine the achievements of the NPTF and the challenges it has faced.

The NPTF has been active for eight years in Nepal. In answer to the question, "How is the NPTF doing?" the majority of respondents to surveys of beneficiaries and stakeholders of NPTF projects in 2014, conducted by the Kathmandu-based research and consultancy firm Interdisciplinary Analysts (IDA), said it was performing "well" or "fairly well" (see Figure 2).

Figure 2. Responses to the Question "How is the NPTF Doing?"

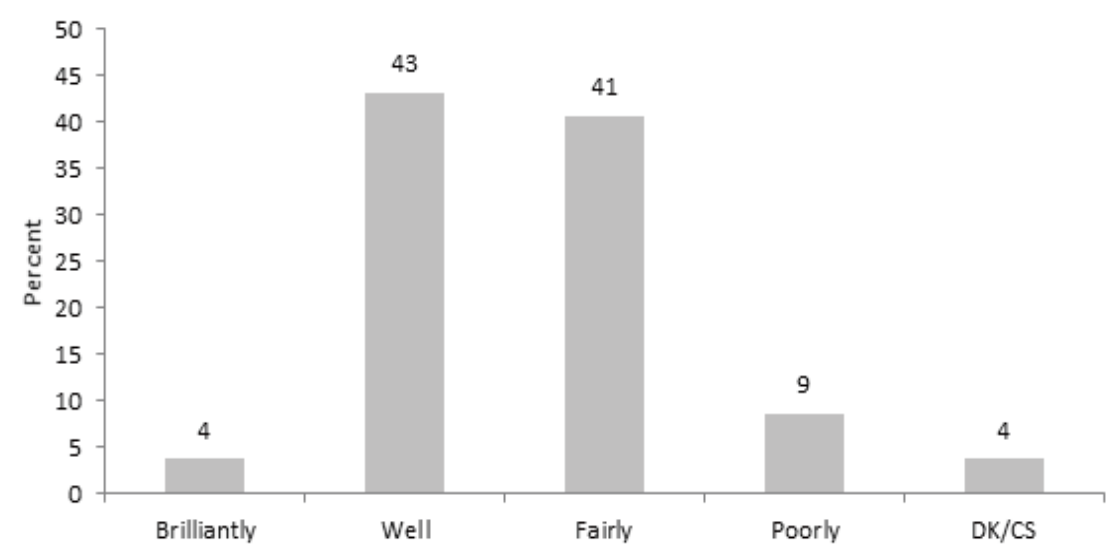

Source: Interdisciplinary Analysts (IDA) Survey 2014.

Notes: DK: Don't know; CS: Can't say.

As per its mandate, the NPTF has been preparing to close down on completion of its third extended term in 2017, but respondents to the 2014 survey feel that it should continue until the many pending issues of the peace process are resolved. The majority of the respondents (78 percent) said that the NPTF is still needed for the longer term, and they also suggested that the NPTF framework should focus on three main areas, namely: support for transitional justice mechanisms; support for genuine, rather than fake, victims of conflict; and reconstruction of the physical infrastructure.

Below, I have noted some key achievements of the NPTF framework over its eight years of existence, as well as some challenges it has faced, based on my field notes:

- The NPTF Secretariat in charge of managing and facilitating the peace process has played a positive role, particularly in managing arms and combatants.

-The NPTF was successful in creating a positive environment in the cantonments, where ex-combatants were held for more than six years. But it was less successful in 
rehabilitating combatants and preparing the communities that would receive them.

-The NPTF modality focused more on managing funds and offering technical support, and it was relatively successful in this. But it failed to stop corruption and the misuse of funds due to weak monitoring mechanisms.

-NPTF projects contributed to improving the quality of life of people living in the vicinity of the cantonments. Unfortunately, after the cantonments were closed down in 2012, most of the physical infrastructure was neglected.

-The NPTF was unable to initiate many projects to support the rehabilitation of people and communities affected by the conflict due to inaccurate lists of victims. No attempts were made to correct these lists.

-Support for transitional justice was the weakest area of the NPTF's work, as transitional justice bodies were not set up until 2014 and they have yet to come into operation due to lack of political cooperation.

-A major challenge for the NPTF was its isolation from the political process.

-The NPTF successfully fulfilled its role of supporting national elections, and elections were free and fair. But although the election process was successful, election-related projects were massively expensive.

-The NPTF achieved success in two major areas of its work: donor harmonization and the coordination of line ministries.

-The NPTF's performance was sometimes weakened by differences between the priorities of donors and those of the government.

\section{Cantonment Management: The Legacy of NPTF Investment}

Everybody needs to show that they are successful. For the NPTF, success is often directly associated with spending on material things. From the list of NPTF spending, it is obvious that the framework had very little involvement with intangible projects. This is not to imply that spending on cantonment management and materials, which helped to make ex-combatants' lives much easier, was wrong. Management of cantonments and ex-combatants was clearly a success story for the NPTF and the entire peace process, but the NPTF did miss some opportunities to focus on intangibles, such as national healing and reconciliation between ex-combatants and the communities to which they returned. Here, I will focus on the NPTF's success in managing cantonments over a long uncertain period, and at the same time I will point to some missed opportunities for real national healing through rehabilitation and reconciliation.

Despite a number of challenges, the demobilization of the Maoist combatants contributed significantly to the conclusion of the peace process within a very difficult environment characterized by growing distrust among political parties and the unraveling of the consensus regarding Nepal's political future. For this reason, the management of the cantonments and the ex-combatants housed in them is considered to be a relatively successful aspect of the NPTF's work (interviews with former coordinator of the Secretariat for Reintegration and Rehabilitation of Maoist Army Combatants [SRRMAC], August 13, 2013, and 
director of the NPTF, July 22, 2013). There is no doubt that it was very difficult to manage the thousands of ex-combatants for more than six years when they were initially supposed to be in the cantonments for only six months (interview with former coordinator of SRRMAC, August 15, 2013). The majority of excombatants were kept in the cantonments (although a few hundred were kept outside to provide security for Maoist leaders) and all the logistic support was provided by the NPTF.

In its management of the cantonments and ex-combatants, the NPTF spent its resources on access roads, physical infrastructure (temporary housing, containers, kitchens, etc.), the supply of utilities, healthcare, solar power and biogas systems, secretarial services, and allowances for ex-combatants (semistructured interviews with two former combatants and an engineer formerly employed at the First Division Headquarters, Chulachuli, Ilam, who was living in the vicinity, August 9, 2013, and one former combatant from the Sixth Division Headquarters, Dasarathpur, Surkhet, living in the vicinity, August 1, 2013). All the projects associated with ex-combatants and cantonment management were completed by the end of 2014. According to the latest data made available by the NPTF, the total budget allocated for this "cluster" up to 2013 was NPR5,539.87 million, which is 24 percent of its total budget (NPTF 2014).

The design and implementation of NPTF projects of this kind were always plagued by delays and uncertainty surrounding the reintegration process for ex-combatants. In the CPA, it was assumed that reintegration would be completed within six months. But in the end it took more than six years. In a 2009 report, the Cantonment Management Office accepted the fact that the initial arrangements inside the cantonments were not satisfactory. The report mentions that government funds made available through the NPTF were barely enough to cover such basic necessities as food, shelter, and sanitation, as well as medical supplies for the ex-combatants. But according to ex-combatants themselves, conditions did improve as the cantonments remained in operation for longer than expected (semi-structured interviews with ex-combatants living near Seventh Division Headquarters, Kailali, January 10-11, 2015, and excombatants living in Dang who had previously lived at Fifth Division Satellite and Headquarters, Rolpa, January 5-6, 2015). As one of the interviewees said, "We could not have continued with what was made available during our initial days in the cantonments, later the situation improved and we were comfortable."

In the IDA survey of ex-combatants, respondents admitted that the infrastructure and services, including allowances, were vital considering that they had to stay in the cantonments for more than six years (IDA 2013, 47). However, in the same survey, when 897 ex-combatants were asked to rate the statement, "The Secretariat has succeeded in effective integration and rehabilitation," 22.7 percent answered "not at all," 19.6 percent said "a little," 34.6 percent said "to some extent," 11.4 percent said "quite a lot," and 10.8 percent said "a lot" (IDA 2013). It is clear 
from these findings that the majority of ex-combatants rated the work carried out by the Peace Fund Secretariat on their behalf as less than satisfactory. However, one former director of the NPTF claimed that it played a very effective role in the construction and maintenance of the physical infrastructure of the cantonment sites (interview with former director of the NPTF, July 22, 2013).

The NPTF was largely ineffective in providing the vocational and/or other training required to prepare ex-combatants and the receiving communities for reintegration/rehabilitation (semi-structured interviews with ex-combatants living near Seventh Division Headquarters, Kailali, January 10-11, 2015, and with ex-combatants in Dang from Fifth Division Satellite and Headquarters, Rolpa, January 5-6, 2015). One combatant currently living in Maharajganj, Kathmandu, who had opted for a voluntary retirement package at the time of discharge from Third Division Headquarters, said, "The majority of the ex-combatants who opted for voluntary retirement were sent back to their communities without any skills development training" (interview, December 12, 2014).

Only one project, out of twenty-two in total supported by the NPTF, was found to provide skills (NPTF 2014). But that project was for only six excombatants who opted for rehabilitation at the time of their discharge. It is evident that there was no program to prepare either the receiving communities or the ex-combatants for their return. Most of the ex-combatants bitterly complained that although they were given a handful of cash by way of a "golden handshake," they were not told how to manage their money. One former rankand-file combatant in Kanchanpur District said, "I joined the insurgency at the age of twelve when I was in class nine. I do not know how to manage money or run a business. They gave me half a million rupees but did not tell me what to do with it. Half of my money was spent in the first month while I was looking for a possible small business. I didn't know what I could do with the rest of the money. I was confused and bought a piece of land" (semi-structured interview, January 11, 2015, at a restaurant at Attariya bus station, Kailali). Most of the excombatants had joined the rebel forces as teenagers, not having completed high school. At the time of their demobilization, they were still young and lacked the skills necessary for employment. It is clear that the NPTF missed the opportunity to prepare both ex-combatants and the receiving communities for successful rehabilitation.

Another weakness most of the interviewees reported was poor monitoring of the cantonments because government and international community representatives were denied access by the Maoist leaders. The NPTF focused its efforts on managing funds rather than offering technical support to improve conditions inside the cantonments. Meanwhile, government officials could not access the cantonments (interviews with the editor of a major Nepali national daily, July 28, 2013, and a former member of the Special Committee on Reintegration and Rehabilitation of Maoist Army Combatants, August 14, 
2013). The weak monitoring mechanism created safe havens for corruption and mismanagement. Most of the ex-combatant interviewees blamed Maoist leaders and commanders for the corruption. The issue of corruption in the cantonment management process is considered the largest corruption scandal involving government-managed funds in the history of Nepal. The issue has been under investigation by the Commission on the Investigation of Abuse of Authority (CIAA) for the last three years.

One former battalion commander from Third Division Headquarters, Chitawan, told how Maoist leaders had misused the Maoists' pool fund (interview, February 17, 2015, Hetauda). He said that all the ex-combatants in the cantonments had agreed to create a pool fund to support disabled combatants and those adversely affected by the conflict. But the funds were misused in an institutionalized way which was very difficult to trace. The problem was often exacerbated by the monitoring authority. According to the interviewee, each ex-combatant agreed to donate NPR1,000 per month out of their allowance to support sick and disabled members of their armed group and the Maoist party. This practice continued until the cantonments were closed. The Maoist leadership never made the fund's accounts public, and it is still a matter of debate in their central committee. Similarly, another ex-combatant from Sixth Division Satellite Cantonment at Lekparsa revealed another example of corruption inside the cantonment (interview, January 2, 2015, Surkhet). He recounted how Maoist commanders were assigned to take charge of construction works inside the cantonments so that NPTF funds could be transferred directly to them by the authorities. The commanders then got ex-combatants living in the cantonments to do the work for nothing. While this system worked in principle, and the monitoring committees found that the projects had been completed in a costeffective way, it gave the commanders an opportunity to exploit free labor and take a cut of the funding. This exacerbated combatants' dissatisfaction with their own leaders and government agencies.

The NPTF's management of the cantonments also had some unintended consequences. I observed some improvements in the quality of life of people living in the vicinity of the cantonment sites as well the inmates themselves. Access roads, electricity and water supplies, healthcare facilities, and other physical infrastructure has benefitted local villagers as well as ex-combatants. The establishment of cantonments also created opportunities for local people to initiate small-scale enterprises. Even after the combatants were discharged, local people were still benefiting from some of these developments. However, the government was unable to decide what to do with this infrastructure once the combatants had left, and much of it has been neglected.

\section{Neglect and Isolation of Conflict Victims}

The neglect and isolation of conflict victims was evident from the very beginning 
of the data collection and documentation period. Now, after over a decade of peace, we still do not have an accurate list of conflict victims. The list compiled by government agencies is contested, as it is subject to political influence and cannot be trusted. The absence of locally elected representative bodies and the lack of any effective local bodies charged with looking after conflict victims meant that most "genuine" victims were isolated from the peace process and those entitled to relief and support were either completely neglected or given insufficient help. NPTF documents claim that the fund supported disabled ex-combatants and victims of the conflict by establishing physical rehabilitation centers. According to one recent NPTF report, the total budget for this kind of work was NPR1,064.83 million, around 5 percent of its total budget (NPTF 2014). The NPTF project lists show that the fund focused on providing centers offering counseling and physical aids for amputees, especially those who had lost legs or hands. Exactly the same model was used to support conflict victims as was used for ex-combatants. But unlike the ex-combatants, the victims were not concentrated in one place, so this model was not suitable for them. This added to the challenges the NPTF encountered in reaching out to victims and providing them with services. Unlike in the case of the ex-combatants, the NPTF failed to provide the victims with adequate tangible support, let alone making sure that displaced people were able to return to their homes, that victims were provided with opportunities to gain vocational skills or find employment, that their children were educated, or that they received financial support or social services.

Displaced people, conflict victims with special needs, and disabled excombatants have all expressed dissatisfaction with the support they have received. Indra Prasad Yadav from Banke District, who lost a leg during the insurgency, was pleased to have been provided with an artificial limb, but he complained that the NPTF had not provided any effective rehabilitation (interview at Hawaldarpur, Banke District, July 30, 2013). It is not only the victims who have complained about this inadequate provision, government officials, including implementing partners, have accepted that there have been shortcomings. The program coordinator of the National Disabled Fund (NDF) explained that the list of conflict victims provided by the Ministry of Peace and Reconstruction was flawed (interview, July 15, 2014). Furthermore, he admitted that "internally displaced people found the relief package very unattractive because they were only entitled to physiotherapy services and minor treatments. In part, their complaints stemmed from the fact that those people travelling from remote areas had to spend more money to travel to the rehabilitation center than they received in support." Meanwhile, Arjun Kunwar, Laddan Jaga, and Hira Budathoki expressed satisfaction with the artificial legs and hands they received at the rehabilitation centers (interviews July 30, 2013, Banke District). Laddan said that the artificial limb was too expensive and he could not afford it, but he got support from the NPTF project. But by the end of 2014, only 350 people out of a total of 
2,750 amputees had received artificial limbs or other aids (NPTF 2014).

There are various reasons for the NPTF's failure to provide adequate support for conflict victims. The main challenge in this area was the difficulty identifying genuine victims, followed by difficulties in reaching them. In 2007, the Ministry of Home Affairs and the Ministry of Peace and Reconstruction drew up a list of around four thousand disabled victims of the conflict (Advocacy Forum 2010; Nepal Monitor 2011). However, a secretary in the Office of the Prime Minister and the Council of Ministers stated that new names were added to the list with every change of government and the list was modified several times in the subsequent six years (interview at Prime Minister's Office, Kathmandu, July 22, 2013). This official further admitted that around 75 percent of those on the list were not genuine victims. During a field visit in 2015, two conflict victims, whose names were not listed, said that political party cadres wanted their names on the list so that they could obtain benefits from the state, while the names of genuine victims were omitted. The NPTF's work was made very difficult by such unreliable data. A senior political journalist on the national daily, Kantipur, who was covering the peace process, suggested that the NPTF could have updated the list with genuine victims but failed to do so (interview, July 26, 2014). In an IDA survey (2013) of conflict victims, 53 percent of respondents thought that victims with disabilities were being denied access to rehabilitation services due to their lack of political connections. As many as 67 percent of beneficiaries did not receive any benefits until after 2012. This evidence from interviewees indicates that the NPTF failed to rehabilitate conflict victims effectively.

\section{Delays in Transitional Justice}

Transitional justice, peace, and security are all very important for a post-conflict country. But in Nepal, the national and local reconciliation process has lagged behind other areas of post-conflict work for almost a decade. As a member of the Truth and Reconciliation Commission complained, "The Truth and Reconciliation Commission was established eight years after the peace agreement, and even now the government is not willing to offer the commission genuine support. They are delaying the adoption of rules and by-laws for the commission without which it cannot operate" (interview, November 10, 2015, Kathmandu). Even though transitional justice is supposed to be the third important theme of the NPTF framework, civil society leaders and journalists that I interviewed in 2014 and 2015 were unaware of any support for transitional justice provided by the NPTF. Although there is no evidence of the NPTF engaging in any activity directly related to transitional justice, NPTF documents show that it has allocated financial resources to this area. The project lists on the NPTF website indicate that the fund's major priorities are the reconstruction of police posts and the provision of training related to peace and security. According to recent data, total investment in this cluster up to 2013 amounted to NPR3,947.83 million, 
comprising about 17 percent of the total NPTF budget (NPTF 2014). Of the 768 police posts destroyed during the armed conflict, a total of 249 are being reconstructed by the Nepal Police with the support of the NPTF. The NPTF also supported a UN Mine Action program. These are the only two relatively effective programs in this area.

One claim that is often heard is that the NPTF could not support transitional justice mechanisms because no such entities were in existence until 2014. Two commissions, namely, the Truth and Reconciliation Commission and the Commission on Investigating Disappeared Persons, were formed in late 2014. But these two commissions are still struggling to function properly due to the lack of clear support from the government and the major political parties. Therefore, it is impossible to evaluate the contribution of the NPTF to transitional justice, although it is possible to examine the NPTF's efforts to improve security in rural areas by supporting the reconstruction of police posts. One can argue that the NPTF framework achieved considerable success in the reconstruction of police posts in various locations. This has helped to reestablish a police presence in remote areas and improved the performance of the Nepal police, contributing to an increased sense of security among the population and improved access to state security institutions. One ex-combatant in a remote village in Dang District confirmed this, saying, "We village people are quite happy and we feel secure as the police post here in our village was restored after fifteen years and the support from the NPTF is praiseworthy" (interview, July 17, 2015, Fulbari Village, Dang District).

Almost all the interviewees criticized the weaknesses in the area of transitional justice. It seems that this issue has been totally overshadowed by the constitution-drafting process and other major changes in the country. The relevant authorities have almost forgotten to address the issues of impunity, justice, and reconciliation for national healing. Work has now started on transitional justice, over a decade after the start of the peace process, though progress is still slow and contested. Nevertheless, interviewees, including the secretary in the Prime Minister's Office, the editor of a major national daily in Kathmandu, and former combatants, all expressed admiration for the NPTF's involvement in reconstructing police posts in different parts of the country. They felt that this work was also necessary for peace, although it was not as important as transitional justice.

\section{Disputes over the Drafting of the Constitution and the Restructuring of the State}

The constitution-drafting process and state restructuring have been at the center of Nepali politics since the peace process started. Though the formal constitutiondrafting process was started in Nepal after the first Constituent Assembly election in 2009, there had already been many disputes and a great deal of turmoil and political drama in the name of constitution drafting and state restructuring since 
the successful conclusion of the popular movement in 2006 and especially after the adoption of the interim constitution in 2007. Though the first Constituent Assembly failed to promulgate a new constitution, the electoral and parliamentary process was relatively successful in preventing overt violence for a long period of time. The NPTF played a crucial supportive role in the success of the first elections for the Constituent Assembly. Besides supporting the electoral process, the NPTF helped the Constituent Assembly Secretariat (CAS) to consolidate public opinion to facilitate the drafting of a new constitution (NPTF 2014). In this area, the NPTF assisted with elections to the Constituent Assembly and other bodies, setting up polling centers and carrying out voter education. The NPTF Programme Document (2010a) claims that this support played an important role in ensuring that the elections were relatively free and fair. The NPTF was supposed to support the democratization process by facilitating national and local elections, but as it turned out, only national elections took place. After the failure of the first Constituent Assembly, the NPTF supported elections for the second assembly in 2013. The elections and the formation of that body put a heavy financial burden on both the government of Nepal and the NPTF. The expenditure on this cluster totaled NPR12,155.20 million, or 54 percent of the total budget, making it the largest of all the four areas of the NPTF's expenditure (NPTF 2014). The huge spending in this area often raises the question of cost effectiveness and the "just" distribution of resources. Other major components of the peace process, such as help for conflict victims, transitional justice, and national healing and reconciliation, were neglected in favor of huge expenditure on the electoral process.

According to the project summary, the bulk of the money was spent on the voter education program, the purchase of stationery and other materials required for holding elections, security expenses incurred by the Election Commission, and daily and travel allowances for commission officials. The allowance paid to officials during the election period was controversial, with the national media criticizing the massive expenditure on allowances (Republica 2013; Election Commission Nepal 2014; Nepal Press Bulletin 2013). A joint secretary of the Election Commission of Nepal reported thus: "One area in which the NPTF was successful was voter registration, with the electoral register being updated and made electronic" (interview, at Election Commission Office, Kathmandu, July $22,2014)$. According to some civil society representatives, although the Election Commission did not succeed in issuing voter identity cards, at least the electronic registration process helped ensure that elections were free and fair (interview with former member of the National Human Rights Commission, Kathmandu, October 10,2014). A lot of NPTF funds were spent on election-related activities, but many people perceived this investment to be less effective than expected (interview with senior journalist on Kantipur national daily, July 26, 2014). Although the purpose of election-related projects was to contribute to democracy 
by ensuring free and fair elections, in some senses it may be said that the money was misspent.

Besides the national elections, the NPTF also supported many peace-related dialogues at national and local level (NPTF 2014). The NPTF provided logistical and financial support for most of the peace dialogues among the major political parties, or between the government and opposition groups and small armed groups, plus other dialogues which were conducted by the Ministry of Peace and Reconstruction. The NPTF secretariat also made its office available as a venue for many dialogues (interviews with a secretary in the Prime Minister's Office and the director of the NPTF, July 22, 2013, Kathmandu). The secretary of the Kailali District Peace Committee and the chair of the Rukum District Peace Committee said that the support of the NPTF did at least help the local peace committees expand to village level, but it was not enough to cover the administrative costs of the office or the cost of organizing various activities at local level (interviews, April 14, 2013, and December 19, 2014).

\section{NPTF Governing Modality: Isolation from the Political Process}

The extension of the peace process beyond the stipulated six months to six years required additional investment which, although it brought added developmental benefits, also created an environment that was conducive to corruption. The Nepalese peace process is seen as being basically home grown because it was led by national leaders and driven by their decisions, with the support of the international community (Grävingholt et al. 2013). The NPTF is a model for this kind of process as it allowed for the involvement of political leaders, donors, and government bureaucrats in decision making. Both the government and donors have contributed to the fund. Implementing the CPA would have been a challenging task even in the best of times. Though the mandate and operations of the NPTF have largely depended on the willingness of political decision makers to provide a framework within which the NPTF can coordinate and implement its projects, the NPTF structure involves not only political players from Nepal, but also donors, government bureaucrats, and consultants hired by the NPTF itself. This creates some very interesting dynamics. From the very beginning, political actors were at the core of this structure. They are the key decision makers, but their role is often limited to "witnessing" the process and signing off decisions, and most of the time they are isolated from the decision-making process because of the political bureaucracy of the donors and the interests of the bureaucrats running the NPTF.

According to the NPTF's director, it has succeeded in creating a basket fund to pool money from the government and eight major donors (interview, July 22, 2013, Kathmandu). The director further explained how the fund had mobilized 
resources through various line ministries to implement projects in different areas. The establishment of the NPTF mechanism reflects the way that both government and donors have prioritized working together to bring the peace process to a logical conclusion. According to its Programme Document (2010a), the NPTF has adopted a two-stage approach to translating its mandate into practical operations: first, the NPTF Board sets the priorities for its work based on an analysis of peacebuilding needs and an assessment of what can be agreed upon and carried out by the NPTF. Second, within the framework provided by the board, the NPTF uses a demand-oriented approach to identify specific projects. But despite what is stated in this document, the NPTF has never been demand oriented. Often, the demands came from government offices, or the technical committee might approach government offices and suggest that they submit a concept note or demands (interviews with implementing partners of the NPTF, including chief administrator, Nepalgunj Physical Rehabilitation Center, July 30, 2013; head of program, Nepal Electricity Authority Surkhet Office, August 2, 2013; and an architect in the Urban Planning Division, Kathmandu). The implementing partners gave the impression that NPTF decision making was mostly dominated by bureaucrats. Furthermore, the NPTF channeled its budget primarily through government bodies, selecting its implementing partners from among state actors. Thus, the NPTF was not responding to demands from its potential beneficiaries but was rather operating on the basis of needs identified by government bureaucrats. And initially, most of its projects were both identified and executed by government bureaucrats to serve their own interests. In the second phase, however, it was opened to non-state actors on a pilot basis. But because of the unwillingness of government bureaucrats and political leaders, NGOs are no longer part of the NPTF framework, or if they are involved, they are limited to small projects within a restricted area.

According to one official, "there was continuous debate over whether to include state actors only or both state and non-state actors in project implementation. Only seven projects were given to national NGOs as pilot projects" (interview with secretary, Ministry of Peace and Reconstruction, September 10, 2015, Kathmandu). Most of the time, government bureaucrats were suspicious of the activities of NGOs in Nepal (interview with member of NGO Federation of Nepal Central Committee, September 7, 2014). Donors complained of slow and inefficient implementation by government actors (interview with a technical advisor to the NPTF from the donors' side, June 26, 2013, NPTF Secretariat). The debates and clash of priorities arose because the NPTF is a joint initiative of government and donors, and the two sides have very different working patterns. The majority of government officials interviewed by the author found the implementation arrangements unusual and unfamiliar (semi-structured interviews with under-secretary and joint secretary of NPTF, June 26, 2013, NPTF Secretariat, Kathmandu). The NPTF is only a coordinating mechanism and 
does not have its own institutional arrangements for implementing projects. It is evident that it has to rely on other government agencies and civil servants. Local government officials in Nepal were already overburdened due to the absence of local elected bodies. The secretary of the Ministry of Peace and Reconstruction said that local officials had to take on NPTF projects in addition to their regular government workload, and they tended to feel less responsibility for them (interview, September 10, 2015).

Another recurring grievance raised by government bureaucrats was that even though most of the NPTF funds (almost 60 percent) come from the government, the government's voice is not sufficiently heard and it is not accorded sufficient "dignity." Both the government bureaucrats and politicians said they felt that the NPTF was dominated by donors (semi-structured interviews with secretary, joint secretary, and under-secretary, Ministry of Peace and Reconstruction, September 10, 2015, June 26, 2013, at their offices in Kathmandu). Representatives of political parties also felt that the NPTF was dominated by donor representatives, peace experts, and the NPTF's own bureaucrats. The political leaders shared the feeling that they were often treated as "passive witnesses" (sakshi kinara ma basne in Nepali) in the NPTF by both the fund's bureaucrats and donors (interview with former minister of peace and reconstruction, August 24, 2013, at her residence). According to the former minister of peace and reconstruction, when it came to approving programs, officials generally handed her thick reports on the day of the meeting and asked her to make a decision. She felt that she had not been given sufficient time to digest the reports and give her opinions.

Another issue regarding the NPTF's governing modality concerns reconstruction. Although reconstruction was a cross-cutting theme of all the projects, the NPTF spent very little money on it. Despite a focus on infrastructure, in practice, very few projects were undertaken (NPTF 2014). Political leaders and government officials felt that donors did not trust them and tended to bristle at unnecessary policy interventions (interviews with secretary, minister, and officials from the Ministry of Peace and Reconstruction). Investment priorities associated with reconstruction were an issue of constant debate. The majority of government officials wanted to invest in infrastructure and construction projects which they considered to be of the highest priority. Donors, on the other hand, prioritized activities such as skills development, capacity building, and counseling. Despite the intense debate, investment in both areas-infrastructure reconstruction and skills development-has been weak throughout the history of the NPTF.

Flawed arrangements for the procurement of goods also constituted a major issue in the initial phase. "The government had suspended the Public Procurement Act to expedite purchases. This had the effect of creating opportunities for corrupt officials and leaders" a senior journalist on the Kantipur newspaper stated. Because of the special provisions, those implementing the projects did not need to follow normal procurement processes. This speeded up 
procurement but facilitated corruption. In the initial phase, it is reported that government agencies did not even keep records of what was bought and from where it was bought.

\section{Conclusion}

The NPTF is a localized case of a unique model which may have far-reaching international implications. The author concludes that the process has produced mixed results. On the whole it has made a significant contribution to the conclusion of the peace process in Nepal in a very difficult environment, although the majority of NPTF projects had only mediocre outcomes.

A decade after the establishment of the NPTF, there are still a lot of issues that need to be addressed if a sustainable peace is to be achieved, even though the government and some other actors claim that the peace process has reached its logical conclusion. The NPTF framework and the peace process as a whole has missed the opportunity to carry out "national healing." The political process has always been focused on the center, and the peace process has not impacted on local life. Families of the disappeared are still suffering; legal obstacles are hampering the resolution of property and other family matters, as the issue of the disappearances has yet to be legally addressed. It is claimed that many genuine victims of the conflict were omitted from the official list, whereas others were included on false pretenses and are enjoying allowances and benefits to which they are not entitled. The majority of ex-combatants did not return to their homes but settled in semi-urban settings, and now they are often having to cope with various psychosocial challenges. In all these cases, "reconciliation and healing" has been absent. Ex-combatants were sent back to society without any counseling or preparation; conflict victims are living very difficult lives, lacking even the barest necessities. More than that, the issue of transitional justice has still not been addressed, meaning that people at the grass roots are suffering every day, something which is ignored by national politicians. From one point of view, the peace process seems to be almost complete and the NPTF is wrapping up its projects. But dissatisfaction with the shortcomings of the process is warning us that there is the possibility of another conflict in the future.

\section{Notes}

This paper was presented at the conference "Post-War Development in Asia and Africa," organized by CEPA, September 1-3, 2014. I would like to acknowledge the contribution of anonymous reviewers, and my friends Surabhi Pudasaini, Sakar Pudasaini, and Chiranjibi Bhandari for assistance with revision. 


\section{References}

Advocacy Forum. 2010. Discrimination and Irregularities: The Painful Tale of Interim Relief in Nepal. Kathmandu: Advocacy Forum.

Cantonment Management Central Coordinator's Office (CMCCO). 2009. “Cantonment Management Project." Project proposal submitted to Ministry of Peace and Reconstruction, Kathmandu.

Crisis Group. 2006. Nepal's Peace Agreement: Making It Work. Asia Report no. 126. Kathmandu and Brussels: Crisis Group.

Election Commission Nepal. 2014. Report on Fifth Meeting of Forum of Election Management Bodies of South Asia. Kathmandu: Election Commission Nepal.

European Parliament. 2016. "EU Should Set Up a Trust Fund to Support Colombia Peace Process, Say MEPs.” http://www.europarl.europa.eu/news/en/newsroom/20160115IPR10179/EU-should-set-up-a-trust-fund-to-support-Colombiapeace-process-say-MEPs (accessed February 15, 2016).

Grävingholt, Jörn, Lennart Bendfeldt, Linda Berk, Yvonne Blos, Charlotte Fiedler, and Karina Mross. 2013. Struggling for Stability: International Support for Peace and Democracy in Nepal. Bonn: German Development Institute.

IDA (Interdisciplinary Analysts). 2013. Vertical Monitoring Report of the NPTF Supported Projects. Unpublished report submitted by IDA, Kathmandu, to Nepal Peace Trust Fund (NPTF), Ministry of Peace and Reconstruction, Nepal.

IDA. 2014. Perception Survey of the Stakeholders of Nepal Peace Trust Fund. Final report of the study conducted by IDA for the Nepal Peace Trust Fund (NPTF), supported by GIZ, Kathmandu.

Mallik, Vidyadhar. 2013. Local and Community Governance for Peace and Development in Nepal. Bonn: German Development Institute.

Ministry of Finance. 2014. "Introduction to International Economic Cooperation Coordination Division.” http://www.mof.gov.np/en/divisions/internationaleconomic-cooperation-coordination-division-36.html (accessed August 5, 2014).

Nepal Dispatch. 2013. "Social Welfare Council to Monitor Activities of NGOs." http://www. nepaldispatch.com/2013/07/social-welfare-council-to-monitor-activities-of-ngos/ (accessed December 23, 2015).

Nepal Monitor. 2011. "Government Relief Efforts for Nepal Conflict Victims." http://www. nepalmonitor.com/2011/07/government_relief_ef.html (accessed September 5, 2015).

Nepal Press Bulletin. 2013. "EC Expends Rs 565 Million in Three Months." http:// www.dewnepal.org.np/uploads/news/file/nepal-press-bulletin-30-oct-2013 20131114113559.pdf (accessed December 17, 2014).

NPTF (Nepal Peace Trust Fund). 2008. “Peace Fund Operation Rule 2065 BS.” Nepal Peace Trust Fund, Ministry of Peace and Reconstruction, Kathmandu.

NPTF. 2010a. "Joint Financial Arrangement (JFA)." Nepal Peace Trust Fund, Ministry of Peace and Reconstruction, Kathmandu.

NPTF. 2010b. "Program Document." Nepal Peace Trust Fund, Ministry of Peace and Reconstruction, Kathmandu.

NPTF. 2014. "Program Document 2014." Nepal Peace Trust Fund, Ministry of Peace and Reconstruction, Kathmandu. 
OECD Joint Evaluation Team. 2013. "The International Support to the Peace Process in Nepal 2006-2012." Ministry of Foreign Affairs of Denmark, Copenhagen.

Orjuela, Camilla. 2005. "Dilemmas of Civil Society Aid: Donors, NGOs and the Quest for Peace in Sri Lanka." Peace and Democracy in South Asia 1 (1): 1-12.

Peace Secretariat, Government of Nepal. 2007. "Agreements and Understandings on Peace Negotiation of Nepal.” http://www.ncf.org.np/upload/files/775_en_cover\%20and\%20 con.pdf (accessed December 21, 2014).

Republica. 2013. "RS 11.5b Released for Election So Far." http://e.myrepublica.com/2014/ component/flippingbook/book/1415-republica-13-nov-2013/1-republica.html (accessed September 15, 2014).

Spotlight. 2012. "INGOs: Mostly Misunderstood." Spotlight Magazine 6 (14). http://www. spotlightnepal.com/News/Article/ingo-nepal-misunderstood (accessed January 11, 2012).

United Nations Nepal Information Platform. 2006. "Comprehensive Peace Agreement Concluded between the Government of Nepal and the Communist Party of Nepal (Maoist)." http://un.org.np/node/10498 (accessed November 17, 2014).

UN Multi-partner Trust Fund Office. 2015. "Portfolio of Funds and Joint Programs Overview." http://mptf.undp.org/portfolio/fund (accessed February 27, 2016).

Uppsala Conflict Data Project. 2013. Political Violence @ a Glance.http:// politicalviolenceataglance.org/tag/uppsala-conflict-data-project/ (accessed September $28,2013)$.

Upreti, Bishnu Raj. 2014. "Peace and Post-conflict Reconstruction in Nepal: A Bird'sEye View.” http://bishnuupreti.blogspot.com/2014/12/peace-and-post-conflictreconstruction.html (accessed December 27, 2014).

Upreti, Bishnu Raj, and Anish Ghimire. 2012. Conflict, Transition, and Challenges to Nepal's Peace Process. Kathmandu: NCCR North-South, South Asia Coordination Office.

Wallensteen, Peter. 2007. Understanding Conflict Resolution. London: SAGE.

Rajib Timalsina is a faculty member in the Department of Conflict, Peace and Development Studies (CPDS), Tribhuvan University, Nepal. He is also a visiting lecturer at the Armed Police Force Staff and Command College in Kathmandu. In 2014-2016 he is serving as convener of the Peace Negotiation and Mediation Commission, International Peace Research Association (IPRA). He has served as a consultant to various research projects related to the peace process in Nepal and the vertical monitoring of Nepal Peace Trust Fund projects. He is broadly interested in the intersection of civics and technology, and has published papers on local and urban governance, security, peace politics, tourism, and peace research methodology. In 2013, he was awarded the Nepal Bidya Bhusan medal for academic excellence from the president of Nepal. E-mail: rajib.timalsina@gmail.com 
